\title{
The Phenomenon of Psychological Operations as a Concept and Discourse (Based on Security Linguistic Cultures of the NATO and the Russian Federation)
}

\section{Феномен психологічних операцій як концепт і дискурс (за матеріалом безпекових лінгвокультур НАТО та Російської Федераціі)}

\section{Larysa Kompantseva}

Dr. in Philology,

Professor
Лариса Компанцева

доктор філологічних наук, професор

E-mail: larafkom@gmail.com

https://orcid.org/0000-0001-7902-9209

ResearcherID: G-7399-2019

\author{
National Academy of \\ the Security Service of Ukraine \\ 22, Maksymovycha Str., Kyiv, \\ Ukraine, 03022
}

Національна академія Служби безпеки України

$\square$ вул. Максимовича, 22, Київ, Україна, 03022

Original manuscript received October 18, 2019

Revised manuscript accepted March 19, 2020

\begin{abstract}
Objective. The purpose of this paper is to present an argument for the status of the phenomenon of psychological operations as a concept and discourse.

Materials and Methods. To achieve the most plausible results, the following integrated methods have been used: semantic and cognitive analysis - to study deep semantic connotations, which are fundamentally different in the linguistic cultures of the NATO and the Russian Federation; concept analysis - to study the regulatory role of the concept PSYCHOLOGICAL OPERATIONS in interstate relations;discourse analysis - to study the consistently situational institutional discourse of psychological operations as a tool for constructing social reality.
\end{abstract}


Results. The discourse of NATO Doctrines has a practical dimension: it focus on developing a positive Alliance image, focusing attention on the diversity of target audiences, building confidence, and supporting military commanders' actions in relation to foreign people. The discourse of the Russian Federation is destructively oriented: the strategies of escaping international responsibility, ignoring diplomatic relations, causing damage comparable to effects of hostilities are exposed as essential. The hidden meanings of the concept PSYCHOLOGICAL OPERATIONS have been identified, namely: such semantic components as "promoting strategic goals to restore and reinforce legitimacy, to alleviate suffering, to maintain and restore public order" are employed in NATO doctrines, whereas the sources of the Russian Federation contain "attack under false colours for the purpose of destabilization and disorientation». Lacunarity is caused by the moral and ethnic perception of the concept PSYCHOLOGICAL OPERATIONS in the linguistic cultures under study.

Conclusions. The discourse of psychological operations is a system; the directions of its deployment in the studied linguistic cultures are fundamentally incongruent. Representation of the concept PSYCHOLOGICAL OPERATIONS in security discourses demonstrates invariant images of the world, correlated with national mind-sets.

Key words: discursive psychology, discursive construction of social reality, lacunarity of concept, concept PSYCHOLOGICAL OPERATIONS, consistently situational institutional discourse of psychological operations, psycholinguistic dimension of the discourse of psychological operations.

\section{Вступ}

Події в Україні 2014-2020 років зумовили зміну статусу маргінальних лінгвістичних дисциплін (психолінгвістики, соціолінгвістики, сугестивної лінгвістики, когнітивної лінгвістики тощо): фахівці, які опікуються питаннями національної безпеки, оцінили їхні прикладні можливості під час здійснення аналізу гібридних загроз і вироблення проактивних технологій протидії. Як результат - значний пласт вузькоспеціалізованих понять безпекової та оборонної сфер набули міждисциплінарного значення й отримали лінгвістичне осмислення. Так, поняття психологічні операціï сьогодні активно застосовується в різних дискурсивних практиках - безпековій, науковій, масмедійній, законотворчій. Його психолінгвістичні характеристики не залишаються поза увагою, більш того - психолінгвістичні дослідження концепту ПСИХОЛОГІЧНІ ОПЕРАЦЇ̈ набувають геополітичної значущості. 
Якщо до початку агресії РФ проти України 2014 року цей концепт був предметом наукового вивчення окремих наукових шкіл, то сьогодні його дослідження набувають транспарадигмальної сутності, а підходи різняться залежно від геополітичного статусу держав, де ініціюються такі пошуки.

Окремі аспекти психологічних операцій досліджені у психолінгвістичному вимірі, наприклад (Haig \& Hajdu, 2017; Ovchinnikova, 2018; Mayweg-Paus \& Jucks, 2018; Шаховский, 2018). Але найбільшою мірою систематизовані психолінгвістичні маркери психологічних операцій науковцями країн НАТО, України та РФ.

Науковим осередком моделювання концепту ПСИХОЛОГІЧНІ ОПЕРАЦІЇ в НАТО є Центр передових технологій стратегічних комунікацій НАTO в Ризі (CE StratCom HATO). Дослідження здійснюються за такими напрямами: психолінгвістичні особливості налагодження комунікацій 3 різними цільовими аудиторіями у ситуації постправди (Granelli, 2018); когнітивні маркери маніпулятивних комунікацій (Fake News: A Roadmap, 2019; Pamment et al., 2018); психолінгвістичний вимір психологічних операцій в соціальних мережах (Holmstrom, 2015; Lange-Ionatamishvili, 2015), зокрема організація діпфейків фальшивих повідомлень, створених за допомогою штучного інтелекту (Shaheen, 2015; The Black Market for Social Media Manipulation, 2018).

В РФ питанню психологічних операцій присвячені наукові пошуки багатьох лінгвістичних шкіл. Так, фахівці Сибірського федерального університету (м. Красноярськ) обгрунтували необхідність запровадження нової лінгвістичної галузі - лінгвістики інформаційно-психологічної війни (Сковородников \& Копнина, 2016; Сковородников, 2017). В Скатеринбурзі лінгвістичний аспект психологічних операцій вивчається науковими школами Інституту філософії та права Уральського відділення Російської академії наук (філософські та психолінгвістичні маркери «м'якої сили») (Русакова \& Русаков, 2017; Русакова \& Грибовод, 2019), Уральського державного педагогічного університету (психолінгвістичні особливості організації дискурсів впливу) (Веснина \& Нахимова, 2017; Дударева, Нахимова \& Рязанцева, 2017), Уральського федерального університету імені Б. Сльцина (конструювання ідентичності під впливом концепту 
ІНФОРМАЦІЙНА ВІЙНА) (Асташова \& Булатова, 2017). У працях Вищої школи журналістики i масових комунікацій СанктПетербурзького державного університету концепт ПСИХОЛОГІЧНІ ОПЕРАЦІЇ розглядається в системі стратегічних комунікацій, досліджуються психолінгвістичні особливості контенту ЗМІ як інструменту психологічних операцій (Лабуш \& Пую, 2019) та психолінгвістичні маркери пропагандистських дискурсів (Сидоров et al., 2019). У пошуках фахівців Московського державного університету ім. М. Ломоносова висвітлено питання психолінгвістичних особливостей медіадискурсу та геоконцептів як маркерів інформаційно-психологічного протистояння (Калуцков, 2017).

В Україні активно розвивається науково-практичний напрям стратегічних комунікацій - «скоординованого i належного використання комунікативних можливостей держави - публічної дипломатії, зв'язків із громадськістю, військових зв'язків із громадськістю, інформаційних та психологічних операцій, заходів, спрямованих на просування цілей держави» (Воєнна доктрина України, 2015). У психолінгвістичному вимірі розглядаються питання сугестії та контрсугестії в гібридній війні (Зеленін, 2015), зокрема крізь призму психологічних операцій (Кудінов et al., 2018), транслювання наративів у мас-медіа (Лисичкіна, 2019), нейромаркетингових технологій впливу (Курбан \& Курбан, 2019), операцій в соціальних мережах (Компанцева, 2018).

Мета цієї статті - обгрунтувати статус феномену психологічних операцій як концепту та дискурсу. Завдання дослідження: 1) здійснити семантико-когнітивний аналіз концепту ПСИХОЛОГЧНІ ОПЕРАЦІЇ в безпекових лінгвокультурах НАТО і РФ; 2) виокремити мінімальні семантичні компоненти термінів, що охоплені тематичною групою «психологічні операції», а також визначити дискурсивні ситуації їхнього застосування з урахуванням доктрин НАТО, в яких вперше у світі було запропоновано тлумачення понять тематичної групи «психологічні операції»; 3) дослідити особливості розгортання послідовно ситуативного інституційного дискурсу психологічних операцій як інструменту конструювання соціальної реальності за матеріалом доктрин НАТО та довідникових видань РФ. 


\section{Методи та методики дослідження}

Аналіз феномену психологічні операщії як концепту і дискурсу передбачає комплексне застосування низки методів задля отримання найдостовірніших результатів. Метод семантико-когнітивного аналізу дефініцій тематичної групи «психологічні операції» дозволив: а) когнітивно проінтерпретувати на основі мінімальних семантичних компонентів сутність концепту ПСИХОЛОГІЧНІ ОПЕРАЦІЇ у досліджуваних безпекових лінгвокультурах; б) вивчити глибинні семантичні конотації, що не охоплені лексикографічними дефініціями, й такі, що $є$ принципово відмінними лінгвокультурах НАТО і РФ.

Кониепт-аналіз дозволив розглянути поняття ПСИХОЛОГІЧНІ ОПЕРАЦІЇ 3 морально-етичних позицій, оскільки саме його моральна, а не пізнавальна складова є регулятивною у внутрішньота міждержавних відносинах. Представленість концепту ПСИХОЛОГІЧНІ ОПЕРАЦІЇ у безпекових лінгвокультурах, що досліджуються, демонструє інваріантні образи світу, співвіднесені 3 національною психологією.

Дискурс-аналіз у межах дискурсивної психології сприяв вивченню послідовно ситуативного інституційного дискурсу психологічних операщій як «результату й інструменту конструювання соціальної реальності» (Филлипс \& Йоргенсен, 2004: 35); визначенню місць неконгруентності (лакун) реалізації, сприймання i розуміння цього дискурсу в різних лінгвокультурах.

\section{Результати та дискусії}

На першому етапі когнітивно проінтерпретовано концепт ПСИХОЛОГІЧНІ ОПЕРАЦІЇ, що в безпекових лінгвокультурах країн НАТО та РФ набув термінологічного статусу. За даними контентаналізу доктрин НАТО тематична група «психологічні операції» містить понад 50 одиниць. В РФ осмислення терміноконцепту ПСИХОЛОГІЧНІ ОПЕРАЦІЇ Подано у спеціалізованих словникахдовідниках (Рогозин, 2016; Вепринцев \& Манойло, 2019), зокрема у військово-технічному словнику «Війна та мир у термінах і визначеннях», автори якого - відомі воєнно-політичні діячі РФ - 
The Phenomenon of Psychological Operations as a Concept...

Д. Рогозін (колишній заступник голови уряду РФ), В. Семін (колишній керівник групи з воєнно-стратегічних питань Постійного представництва РФ при НАТО), Д. Лоскутов (керівник групи воєннотехнічної і оборонної співпраці Постійного представництва РФ при НАТО). Цей словник «широко використовується у роботі Ради безпеки, Міністерства оборони, Міністерства закордонних справ, Генштабу 3С, міжнародних секретаріатів СНД, ОДКБ (організації договору з колективної безпеки) і ШОС (Шанхайської організації співробітництва, а також військовими оглядачами провідних 3МІ» (Рогозин, 2016), що є свідченням форматування картини світу нації під потреби національної безпеки.

Семантико-когнітивна інтерпретація лексикографічних джерел довела близькість визначень поняття психологічні операції у документах НАТО і РФ, але не їхню тотожність. У російських джерелах психологічні операції (інформаційно-психологічні операції) визначено як 1) інформаційні дії збройних сил, що призводять до деморалізації та дезорганізації противника; 2) у широкому сенсі - цілеспрямована діяльність будь-яких урядових і неурядових структур у мирний час, загрозливий період або воєнний час, яка має на меті зміну поглядів противника, союзника чи нейтральних аудиторій, представників ЗС або цивільних осіб у вигідний для ініціатора такої діяльності бік. Психологічні операції містять агітацію, пропаганду та інші сплановані дії, що забезпечують вплив на свідомість, емоції, мотиви, міркування, переконання в особистій правоті та, врешті, поведінку цільової аудиторії (Рогозин, 2016). У доктринах НАТО під психологічними операціями (операціями психологічної війни) розуміється 1) спланована діяльність із застосуванням методів комунікації та інших засобів, спрямована на певну аудиторію 3 метою впливу на іiі сприйняття, ставлення та поведінку, які б сприяли досягненню певних політичних та військових цілей (DOD Dict. 2017); 2) сплановані психологічні дії, які використовують комунікації та інші заходи, спрямовані на зміну сприйняття, ставлення до чогось та поведінку цільової аудиторії, що впливають на досягнення політичних або військових цілей (AАР-06, 2014).

Спільними є семантичні компоненти - вплив на певні цільові аудиторії та системність. 
Відмінності полягають у визначенні цілей і об’єкта впливу психологічних операцій. У джерелах РФ визначено суто деструктивні цілі психологічних операцій - «деморалізація та дезорганізація»; у джерелах НАТО - стратегічні цілі - «досягнення політичних або військових иілей», що не обмежуються деструктивним компонентом, зокрема в доктринах AAP-06 (2014), AJP-3.10.1 (2015), DOD Dict. (2017), IMSM-0129-2018 (2018) наведено такі цілі, як «забезпечення співробітництва дружніх чи нейтральних країн», «надання командуванню свободи дій». Підхід науковців РФ передбачає вплив на всі складові структури особистості - спрямованість, здібності, характер, систему управління і психічні процеси («забезпечують вплив на свідомість, емочіiі, мотиви, міркування, переконання в особистій правоті та, врешті, поведінку изільової аудиторії») (Рогозин, 2016), підхід фахівців країн НАТО - лише на спрямованість і характер «сприйняття, ставлення та поведінку»). Отже, концепт ПСИХОЛОГІЧНІ ОПЕРАЦІЇ є неконгруентним у досліджуваних лінгвокультурах за параметрами цілей і об'єкта.

На другому emani вирішувалося завдання 2 дослідження на основі доктрин НАТО виокремлено мінімальні семантичні компоненти термінів тематичної групи «психологічні операції», визначено психолінгвістичні особливості їхнього застосування у дискурсивних практиках.

Таблиця 1. Тематична група «психологічні операції»: семантико-когнітивна i дискурсивна інтерпретації

\begin{tabular}{|c|c|c|c|}
\hline Термін & $\begin{array}{c}\text { Визначення } \\
\text { (за класифікацісю } \\
\text { НАТО) }\end{array}$ & $\begin{array}{l}\text { Семантичні } \\
\text { компоненти }\end{array}$ & $\begin{array}{c}\text { Психолінгвістичні } \\
\text { особливості } \\
\text { застосування в } \\
\text { дискурсивних } \\
\text { практиках }\end{array}$ \\
\hline $\begin{array}{l}\text { асиметрична } \\
\text { загроза }\end{array}$ & $\begin{array}{l}\text { Загроза, що походить від } \\
\text { потенційного противника } \\
3 \text { метою використання } \\
\text { його слабких місць } \\
\text { для отримання } \\
\text { диспропорційного } \\
\text { результату (ААР-06, 2014) }\end{array}$ & $\begin{array}{l}\text { • застосування } \\
\text { різнорідних засобів та } \\
\text { методів; } \\
\text { • ведення противника } \\
\text { в оману; } \\
\text { • нейтралізація сил } \\
\text { противника; } \\
\text { • диспропорційний } \\
\text { результат }\end{array}$ & $\begin{array}{l}\text { • } \quad \text { вплив на } \\
\text { противника } \\
\text { для отримання } \\
\text { диспропорційного } \\
\text { результату; } \\
\text { • запобігання } \\
\text { досягненню } \\
\text { противником певної } \\
\text { комунікативної цілі; } \\
\text { • здійснення } \\
\text { сугестивного впливу }\end{array}$ \\
\hline
\end{tabular}




\begin{tabular}{|c|c|c|c|}
\hline $\begin{array}{l}\text { бажане } \\
\text { сприйняття } \\
\text { (погляди) }\end{array}$ & $\begin{array}{l}\text { Під час операцій, } \\
\text { метою яких є введення } \\
\text { противника в оману, - } \\
\text { погляди об'єкта операції, } \\
\text { його сприйняття ситуації, } \\
\text { результатом яких є } \\
\text { досягнення цілей такої } \\
\text { операції (FM 3-13 } \\
\text { IO:DTTP, 2016) }\end{array}$ & $\begin{array}{l}\text { - введення противника } \\
\text { в оману, } \\
\text { • погляди об’єкта } \\
\text { операції, } \\
\text { • сприйняття об'єктом } \\
\text { операції ситуації, } \\
\text { • досягнення цілей } \\
\text { психологічної операції. }\end{array}$ & $\begin{array}{l}\text { в використання } \\
\text { мовних і } \\
\text { дискурсивних засобів } \\
\text { для навмисного } \\
\text { втручання в } \\
\text { процеси психічного } \\
\text { відображення } \\
\text { дійсності }\end{array}$ \\
\hline $\begin{array}{l}\text { ключовий } \\
\text { символ } \\
\text { (образ) }\end{array}$ & $\begin{array}{l}\text { Під час проведення } \\
\text { психологічних операцій - } \\
\text { простий, сугестивний, } \\
\text { повторюваний символ } \\
\text { (ритм, знак, колір тощо), } \\
\text { який має безпосередній } \\
\text { вплив на цільову } \\
\text { аудиторію та створює } \\
\text { сприятливі умови для } \\
\text { сприймання певної } \\
\text { психологічної теми } \\
\text { (ААР-06, 2014) }\end{array}$ & $\begin{array}{l}\text { - моделювання, } \\
\text { - } \text { новний знак, } \\
\text { - встанний знак, } \\
\text { • вплив }\end{array}$ & $\begin{array}{l}\text { м моделювання } \\
\text { і аналіз процесів } \\
\text { сприйняття мовних і } \\
\text { немовних знаків; } \\
\text { • сугестивний вплив } \\
\text { на цільові аудиторії; } \\
\text { • формування } \\
\text { іміджу; } \\
\text { • формування } \\
\text { картини світу }\end{array}$ \\
\hline $\begin{array}{l}\text { битва } \\
\text { наративів }\end{array}$ & $\begin{array}{l}\text { Повномасштабна } \\
\text { битва в когнітивному } \\
\text { вимірі інформаційного } \\
\text { середовища } 3 \text { метою } \\
\text { успішного встановлення } \\
\text { причин та потенційних } \\
\text { наслідків конфлікту } \\
\text { (Commander's } \\
\text { Handbook for Strategic } \\
\text { Communication, 2017) }\end{array}$ & $\begin{array}{l}\text { повномасштабна } \\
\text { битва; } \\
\text { • битва в } \\
\text { когнітивному вимірі; } \\
\text { • інформаційне } \\
\text { середовище; } \\
\text { • встановлення причин } \\
\text { конфлікту; } \\
\text { • встановлення } \\
\text { потенційних наслідків } \\
\text { конфлікту; } \\
\text { • конфлікт }\end{array}$ & $\begin{array}{l}\text { картини світу нації, } \\
\text { суспільства, людини; } \\
\text { • створення } \\
\text { «реального } \\
\text { майбутнього» через } \\
\text { переосмислення } \\
\text { історії, розширення } \\
\text { системи смислів; } \\
\text { • формування } \\
\text { позиції у внутрішньо-, } \\
\text { міждержавних } \\
\text { конфліктах }\end{array}$ \\
\hline $\begin{array}{l}\text { вводити в } \\
\text { оману }\end{array}$ & $\begin{array}{l}\text { 1. Навмисно змушувати } \\
\text { когось вірити в } \\
\text { неправдивість певного } \\
\text { явища, факту тощо. } \\
2 . \text { Введення осіб, які } \\
\text { приймають рішення, в } \\
\text { оману, маніпулюючи } \\
\text { їхнім сприйняттям } \\
\text { дійсності та переконуючи } \\
\text { їх іти певним курсом } \\
\text { (ААР-06, 2014) }\end{array}$ & $\begin{array}{l}\text { навмисність } \\
\text { в } \text { змушувати когось } \\
\text { вірити; } \\
\text { • мушувати вірити в } \\
\text { неправдивість певного } \\
\text { явища, факту тощо; } \\
\text { • маніпуляція } \\
\text { сприйняттям дійсності; } \\
\text { • переконання щодо } \\
\text { прийняття певного } \\
\text { курсу }\end{array}$ & $\begin{array}{l}\text { картини світу нації, } \\
\text { суспільства, людини; } \\
\text { с моделювання } \\
\text { бажаної поведінки } \\
\text { із застосуванням } \\
\text { сугестивних } \\
\text { механізмів впливу }\end{array}$ \\
\hline $\begin{array}{l}\text { інформаційне } \\
\text { середовище }\end{array}$ & $\begin{array}{l}\text { Середовище, що } \\
\text { складається з самої } \\
\text { інформації; осіб, } \\
\text { організацій та систем, які }\end{array}$ & $\begin{array}{l}\text { сукупність } \\
\text { інформації, осіб, } \\
\text { організацій та систем; } \\
\text { - отримання, }\end{array}$ & $\begin{array}{l}\text { застосування } \\
\text { множинності } \\
\text { дискурсів певної } \\
\text { спрямованості в }\end{array}$ \\
\hline
\end{tabular}




\begin{tabular}{|c|c|c|c|}
\hline & $\begin{array}{l}\text { отримують, обробляють } \\
\text { та передають інформацію; } \\
\text { а також когнітивного, } \\
\text { віртуального та фізичного } \\
\text { простору, в якому це все } \\
\text { відбувається (IMSM-0129, } \\
\text { 2018) }\end{array}$ & $\begin{array}{l}\text { оброблення, передача } \\
\text { інформації; } \\
\text { • система } \\
\text { когнітивного, } \\
\text { віртуального та } \\
\text { фізичного просторів }\end{array}$ & $\begin{array}{l}\text { певний проміжок часу, } \\
\text { їх зв’язку між собою; } \\
\text { • ментальні } \\
\text { репрезентації подій } \\
\text { (суб'єктивні бачення); } \\
\text { • візуалізація } \\
\text { контенту }\end{array}$ \\
\hline $\begin{array}{l}\text { культурне } \\
\text { усвідомлення }\end{array}$ & $\begin{array}{l}\text { Усвідомлення поточних } \\
\text { та історичних цінностей, } \\
\text { норм і вірувань, які } \\
\text { відображаються в різних } \\
\text { соціальних структурах, } \\
\text { зокрема в тому, як вони } \\
\text { впливають на мотиви, } \\
\text { наміри та поведінку } \\
\text { суб’єкта дії } \\
\text { (JDP 2-00, 2000) }\end{array}$ & $\begin{array}{l}\text { • усвідомлення } \\
\text { цінностей, норм і } \\
\text { вірувань суб'єкта дії, } \\
\text { • відображення } \\
\text { цінностей, норм і } \\
\text { вірувань суб’єкта дії } \\
\text { в різних соціальних } \\
\text { структурах; } \\
\text { • вплив цінностей, } \\
\text { норм і вірувань суб'єкта } \\
\text { дії на мотиви, наміри та } \\
\text { поведінку суб'єкта дії }\end{array}$ & $\begin{array}{l}\text { • використання } \\
\text { культурних } \\
\text { стереотипів, } \\
\text { ключових слів } \\
\text { і образів для } \\
\text { формування бажаної } \\
\text { поведінки певної } \\
\text { цільової аудиторії }\end{array}$ \\
\hline $\begin{array}{l}\text { меседж/ } \\
\text { повідомлення }\end{array}$ & $\begin{array}{l}\text { Будь-яка думка або ідея, } \\
\text { виражена зрозумілою } \\
\text { мовою або зашифрована, } \\
\text { підготовлена в належній } \\
\text { формі для транслювання } \\
\text { з використанням } \\
\text { будь-яких засобів } \\
\text { комунікації } \\
\text { (IMSM-0129, 2018) }\end{array}$ & $\begin{array}{l}\text { • думка або ідея, } \\
\text { виражена зрозумілою } \\
\text { мовою; } \\
\text { • думка або ідея } \\
\text { зашифрована, думка } \\
\text { або ідея, підготовлена в } \\
\text { належній формі; } \\
\text { • транслювання думки } \\
\text { або ідеї будь-якими } \\
\text { засобами комунікації }\end{array}$ & $\begin{array}{l}\text { - застосування } \\
\text { дискурсивних } \\
\text { стратегій і тактик, } \\
\text { мовних засобів, } \\
\text { що забезпечують } \\
\text { усвідомлення } \\
\text { меседжа цільовими } \\
\text { аудиторіями }\end{array}$ \\
\hline на & $\begin{array}{l}\text { 2. Виклад думок } \\
\text { або поглядів певної } \\
\text { організації у формі } \\
\text { фундаментальної та } \\
\text { змістовної історії } \\
\text { стосовно того, що собою } \\
\text { являє ця організація, } \\
\text { які основні принципи } \\
\text { їі діяльності та чого } \\
\text { вона прагне досягти } \\
\text { (АЈР-3.10.1, 2015) }\end{array}$ & $\begin{array}{l}\text { • } \quad \text { письмовий або } \\
\text { усний виклад; } \\
\text { • } \quad \text { виклад певних подій; } \\
\text { • виклад поглядів; } \\
\text { • виклад цілей і } \\
\text { принципів діяльності } \\
\text { організації; } \\
\text { • фундаментальна } \\
\text { історія організації }\end{array}$ & $\begin{array}{l}\text { - формування } \\
\text { переконливих } \\
\text { сюжетних ліній щодо } \\
\text { певних ситуацій - } \\
\text { геополітичних, } \\
\text { державних, } \\
\text { інституційних, } \\
\text { особистісних тощо }\end{array}$ \\
\hline $\begin{array}{l}\text { пропаганда } \\
\text { серед } \\
\text { цивільного }\end{array}$ & $\begin{array}{l}\text { Спланована психологічна } \\
\text { діяльність під час кризи } \\
\text { та війни, спрямована }\end{array}$ & $\begin{array}{l}\text { - спланована } \\
\text { психологічна } \\
\text { діяльність; }\end{array}$ & $\begin{array}{l}\text { с системна } \\
\text { координація i } \\
\text { комунікація } 3\end{array}$ \\
\hline
\end{tabular}




\begin{tabular}{|c|c|c|c|}
\hline $\begin{array}{l}\text { населення на } \\
\text { окупованій } \\
\text { противником } \\
\text { території }\end{array}$ & $\begin{array}{l}\text { на цивільне населення, } \\
\text { що проживає на } \\
\text { підконтрольних дружнім } \\
\text { військам територіях, } \\
\text { із метою формування } \\
\text { бажаної поведінки, яка } \\
\text { б сприяла досягненню } \\
\text { військових цілей та } \\
\text { надавала командуванню } \\
\text { свободу дій (ААР-06, } \\
\text { 2014) }\end{array}$ & $\begin{array}{l}\text { - психологічна } \\
\text { діяльність під час } \\
\text { кризи та війни; } \\
\text { • психологічна } \\
\text { діяльність, спрямована } \\
\text { на цивільне населення } \\
\text { підконтрольних } \\
\text { дружнім військам } \\
\text { територій; } \\
\text { • формування бажаної } \\
\text { поведінки; } \\
\text { • сприяння досягненню } \\
\text { військових цілей; } \\
\text { • надання } \\
\text { командуванню свободи } \\
\text { дій }\end{array}$ & $\begin{array}{l}\text { використанням } \\
\text { лінгвістичних, } \\
\text { нейролінгвістичних } \\
\text { засобів впливу на } \\
\text { цільові аудиторії }\end{array}$ \\
\hline $\begin{array}{l}\text { стратегічні } \\
\text { психологічні } \\
\text { заходи }\end{array}$ & $\begin{array}{l}\text { Заплановані психологічні } \\
\text { заходи в мирний час, } \\
\text { під час кризи та війни, } \\
\text { основним завданням яких } \\
\epsilon \text { забезпечення сприяння } \\
\text { або співробітництва } \\
\text { дружніх чи нейтральних } \\
\text { країн, а також зменшення } \\
\text { здатності ворожих або } \\
\text { потенційно ворожих країн } \\
\text { вести війну (ААР-06, } \\
\text { 2014) }\end{array}$ & $\begin{array}{l}\text { - заплановані } \\
\text { психологічні заходи; } \\
\text { • психологічні заходи } \\
\text { в мирний час, під час } \\
\text { кризи та війни; } \\
\text { • забезпечення } \\
\text { співробітництва } \\
\text { дружніх чи } \\
\text { нейтральних країн; } \\
\text { • зменшення здатності } \\
\text { ворога вести війну }\end{array}$ & $\begin{array}{l}\text { с стратегічне } \\
\text { формування } \\
\text { картини світу нації, } \\
\text { суспільства, людини; } \\
\text { · стратегічне } \\
\text { моделювання } \\
\text { бажаної поведінки } \\
\text { із застосуванням } \\
\text { сугестивних } \\
\text { механізмів впливу; } \\
\text { • координація } \\
\text { комунікативних } \\
\text { засобів задля } \\
\text { вирішення конфліктів } \\
\text { та забезпечення } \\
\text { співробітництва }\end{array}$ \\
\hline $\begin{array}{l}\text { цільова } \\
\text { аудиторія }\end{array}$ & $\begin{array}{l}\text { Особа або група осіб, } \\
\text { відібрана } з \text { метою впливу } \\
\text { або атаки на них під час } \\
\text { реалізації психологічних } \\
\text { операцій } \\
\text { (ААР-06, 2014) }\end{array}$ & $\begin{array}{l}\text { оссба або група } \\
\text { осіб; } \\
\text { - особа або група осіб } \\
\text { спеціально відібрані; } \\
\text { • особа або група } \\
\text { осіб, на яких } \\
\text { здійснюється вплив } \\
\text { або атака під час } \\
\text { психологічних операцій }\end{array}$ & $\begin{array}{l}\text { формування } \\
\text { картини світу } \\
\text { цільової аудиторії, } \\
\text { • моделювання } \\
\text { бажаної поведінки } \\
\text { із використанням } \\
\text { сугестивних } \\
\text { механізмів впливу }\end{array}$ \\
\hline
\end{tabular}

Семантико-когнітивний аналіз термінів НАТО, що відносяться до тематичної групи «психологічні операції», довів таке:

1. У досліджуваній групі частотними є семантичні компоненти цінності, картина світу, мовний знак, психологічний вплив, що є свідченням психолінгвістичної природи психологічних операцій. 
2. Спостерігається певна опозиція семантичних компонентів негативної та позитивної конотацій, що фіксує причиново-наслідкові зв'язки між методами негативного впливу на цільові аудиторії (введення в оману, нейтралізація, формування бажаної поведінки тощо) й прогнозованим конструктивним результатом психологічних операцій (досягнення військових иілей, забезпечення співробітництва дружніх чи нейтральних крайн, надання командуванню свободи дій).

3. Об'єкти психологічних операцій, відповідно й цільові аудиторії, втілюються в опозицію свої (дружні країни, командування) - чужі (ворог, противник) й проміжною категорією (нейтральні краӥни; цивільне населення територій, підконтрольних дружнім військам).

4. Лінгвістичні механізми $є$ провідними у формуванні дискурсу психологічних операцій, їх систематизовано за такою ієрархією: стратегічне планування дискурсу - моделювання переконливих сюжетних ліній щзодо певних ситуацій (геополітичних, державних, інституціийних, особистісних) - артикулювання наративів $і$ меседжів - вибір комунікативних стратегій $і$ тактик психологічних впливів - координування комунікативних засобів відповідно до розвитку дискурсу - застосування сугестивних мовних засобів.

5. Семантико-когнітивний аналіз дозволяє стверджувати, що дискурс психологічних операцій $є$ системою та результатом конструювання соціальної реальності, а тому має досліджуватися у межах дискурсивної психології, тобто на перетині лінгвістичної та психологічної парадигм.

6. На третьому етапі здійснено аналіз напрямів розгортання дискурсу психологічних операцій у безпекових традиціях НАТО і РФ як інструменту конструювання соціальної реальності.

Таблиця 2. Порівняльний аналіз напрямів розгортання дискурсу психологічних операцій у безпекових традиціях НАТО і РФ

\begin{tabular}{|c|c|c|}
\hline $\begin{array}{l}\text { Напрям } \\
\text { розгортання } \\
\text { дискурсу }\end{array}$ & $\begin{array}{c}\text { Підхід НАТО } \\
\text { (за: IMSM-0129-2018, 2018) }\end{array}$ & $\begin{array}{c}\text { Підхід РФ } \\
\text { (за: Вепринцев \& Манойло, 2019) }\end{array}$ \\
\hline $\begin{array}{l}\text { Формування } \\
\text { іміджу }\end{array}$ & $\begin{array}{l}\text { формування позитивного іміджу } \\
\text { армії певної країни та країн- } \\
\text { союзниць }\end{array}$ & \\
\hline
\end{tabular}




\begin{tabular}{|c|c|c|}
\hline $\begin{array}{l}\text { Увага до } \\
\text { різноманітності } \\
\text { цільових } \\
\text { аудиторій }\end{array}$ & $\begin{array}{l}\text { зосередження уваги на етнічних, } \\
\text { культурних, релігійних та } \\
\text { економічних розбіжностях } \\
\text { цільових аудиторій }\end{array}$ & \\
\hline $\begin{array}{l}\text { Очікувані } \\
\text { результати }\end{array}$ & $\begin{array}{l}\text { • } \text { вплив на ставлення і поведінку } \\
\text { населення іноземних країн } \\
\text { шляхом суб'єктивного відтворення } \\
\text { інформації для отримання } \\
\text { підтримки країни, що здійснює } \\
\text { психологічні операції; } \\
\text { • поширення серед населення } \\
\text { іноземних країн інформації з } \\
\text { метою підтримання суспільної } \\
\text { діяльності, відновлення та } \\
\text { укріплення легітимності, } \\
\text { полегшення страждань, } \\
\text { підтримання та відновлення } \\
\text { громадського порядку }\end{array}$ & $\begin{array}{l}\text { • відсутність матеріальних } \\
\text { доказів агресії, за допомогою яких } \\
\text { можливо встановити справжнього } \\
\text { агресора та притягнути його до } \\
\text { відповідальності за міжнародним } \\
\text { законодавством; } \\
\text { • сприятливі умови для } \\
\text { заподіяння жертві агресії } \\
\text { (в умовах мирного співіснування) } \\
\text { шкоди, яку можна порівняти } \\
\text { з наслідками бойових дій на } \\
\text { ії території, без спеціального } \\
\text { оголошення війни або будь-яких } \\
\text { інших змін дипломатичних } \\
\text { відносин; } \\
\text { • ідеальні умови для маскування } \\
\text { та приховування справжніх } \\
\text { намірів, можливість діяти під } \\
\text { чужим прапором }\end{array}$ \\
\hline $\begin{array}{l}\text { Досягнення } \\
\text { воснних цілей }\end{array}$ & $\begin{array}{l}\text { підтримання дій командування } \\
\text { щодо населення іноземних держав } \\
3 \text { метою зміцнення довіри }\end{array}$ & $\begin{array}{l}\text { відсутність необхідності фізичного } \\
\text { вторгнення на територію } \\
\text { противника і окупації цієї } \\
\text { території для досягнення своїх } \\
\text { цілей }\end{array}$ \\
\hline $\begin{array}{l}\text { Протидія } \\
\text { інформаційно- } \\
\text { психологічним } \\
\text { впливам }\end{array}$ & $\begin{array}{l}\text { протидія ворожій пропаганді, } \\
\text { поширенню дезінформації та } \\
\text { інформації сумнівного змісту } \\
3 \text { метою позбавлення інших } \\
\text { можливості поширювати погляди, } \\
\text { що наносять шкоду політиці } \\
\text { країни та союзників }\end{array}$ & $\begin{array}{l}\text { відсутність військово-політичних } \\
\text { блоків, союзів і коаліцій, } \\
\text { покликаних забезпечувати } \\
\text { колективну безпеку від зовнішньої } \\
\text { агресії в інформаційно- } \\
\text { психологічній сфері, що } \\
\text { залишає жертву інформаційно- } \\
\text { психологічної агресії один на } \\
\text { один з агресором без будь- } \\
\text { якої заздалегідь підготовленої } \\
\text { підтримки ззовні }\end{array}$ \\
\hline
\end{tabular}

Дискурс-аналіз дозволяє стверджувати, що дискурс психологічних операцій $є$ послідовно ситуативним як у традиціях НАТО, так й у традиціях РФ. У той же час напрями розгортання цього дискурсу у досліджуваних безпекових лінгвокультурах є принципово неконгруентними. Якщо в лінгвокультурі НАТО дискурс психологічних операцій позиціонується як одна 3 комунікативних можливостей, метою якої $є$ просування стратегічних 
цілей, зокрема «отримання підтримки місцевого населення», «підтримання суспільної діяльності, відновлення та укріплення легітимності, полегшення страждань, підтриманні та відновленні громадського порядку», то в лінгвокультурі РФ - як «маскування та приховування справжніх намірів», «можливість діяти під чужим прапором», «відсутність матеріальних доказів агресії, за допомогою яких можливо встановити справжнього агресора та притягнути його до відповідальності за міжнародним законодавством». Дискурс НАТО орієнтований на формування позитивного іміджу Альянсу, зокрема безпекових інституцій країн-учасниць, привернення уваги та покриття якнайбільшої цільової аудиторії, зміцнення довіри, підтримання дій командування щодо населення іноземних держав; дискурс РФ - на уникнення міжнародної відповідальності, ігнорування дипломатичних відносин, нанесення шкоди, «яку можна порівняти $з$ наслідками бойових дій».

\section{Висновки}

Результати семантико-когнітивного аналізу довели, що в безпекових лінгвокультурах країн НАТО і РФ відбулася термінологізація концепту ПСИХОЛОГІЧНІ ОПЕРАЦЇ, що $\epsilon$ частково лакунарним за параметрами цілі та об'єкта психологічного впливу. Принципово відмінними $є$ визначення цілей психологічних операцій джерелами РФ і НАТО: у дискурсах РФ ці цілі відносяться до оперативного рівня комунікацій i $\epsilon$ деструктивно орієнтованими («деморалізаџія та дезорганізація»); у дискурсах НАТО - цілі психологічних операцій є конструктивно орієнтованими і визначаються від стратегічного («досягнення політичних або військових ичілей»), до оперативного («забезпечення співробітництва дружніх чи нейтральних країн») і тактичного («надання командуванню свободи дій»). Водночас, підхід РФ до психологічних операцій визначаємо як антроподеструктивний, оскільки він передбачає руйнівний вплив на всі складові структури особистості - спрямованість, здібності, характер, систему управління i психічні процеси; підхід НАТО - як антропоорієнтований i менш травматичний, орієнтований на корекцію ставлення i поведінки особи. 
The Phenomenon of Psychological Operations as a Concept...

Психологічні операції мать психолінгвістичну природу, підтвердженням чого є результати концепт-аналізу доктрин НАТО: серед мінімальні семантичні компоненти термінів, які охоплюються тематичною групою «психологічні операції», виокремлено «цінності», «картина світу», «мовний знак», «психологічний вплив». Дискурсивним ситуаціям здійснення психологічних операцій притаманна семантико-когнітивна опозиція методи негативного впливу на цільові аудиторії («введення в оману», «нейтралізація», «формування бажаної поведінки» тощо) передбачають конструктивні результати («досягнення військових цілей», «забезпечення співробітництва дружніх чи нейтральних краӥн», «надання командуванню свободи дій»). Лінгвістичні механізми як провідний інструмент організації дискурсу психологічних операцій можуть бути представлені системою: стратегічне планування дискурсу моделювання переконливих сюжетних ліній щуодо певних ситуацій (геополітичних, держсавних, інституційних, особистісних) артикулювання наративів $i$ меседжів - вибір комунікативних стратегій $i$ тактик психологічних впливів - координування комунікативних засобів відповідно до розвитку дискурсу застосування сугестивних мовних засобів.

Отже, статус психологічних операцій може бути ідентифікований як дискурс i концепт. Дискурс психологічних операцій $є$ системою та результатом конструювання соціальної реальності, напрями його розгортання у досліджуваних безпекових лінгвокультурах $є$ принципово неконгруентними: конструктивний вимір доктрин НАТО (спрямованість на формування позитивного іміджу Альянсу, привернення уваги до різноманітності цільових аудиторій, зміцнення довіри, підтримання дій командування щодо населення іноземних держав), деструктивний - довідникових джерел РФ (орієнтація на уникнення міжнародної відповідальності, ігнорування дипломатичних відносин, нанесення шкоди, порівняної 3 наслідками бойових дій).

Репрезентативність концепту ПСИХОЛОГІЧНІ ОПЕРАЦІЇ у безпекових лінгвокультурах, зумовлена інваріантністю образів світу, особливостями національної психології: в документах НАТО позиціонується семантичний компонент концепту ПСИХОЛОГІЧНІ ОПЕРАЦІЇ «Просування стратегічних цілей задля відновлення та укріплення легітимності, полегшення страждань, підтримання 
та відновлення громадського порядку», в джерелах РФ - «напад під чужим прапором 3 метою дестабілізації та дезорієнтації». Лакунарність обумовлена морально-етнічним сприйняттям концепту ПСИХОЛОГІЧНІ ОПЕРАЦІЇ у досліджуваних лінгвокультурах, що наразі зумовлює систему дій державних і безпекових інституцій в умовах асиметричних викликів національній безпеці.

\section{Література}

Асташова, О.И., \& Булатова, Э.В. (2017). Проблемь конструирования идентичности россиян в дискурсе СМИ под влиянием кониепта «информационная война». Москва; Екатеринбург: Кабинетный ученый.

Вепринцев, В.Б., \& Манойло, А.В. (2019). Операџчии информационнопсихологической войны: краткий энщиклопедический словарь-справочник. Москва: Радио и связь.

Веснина, Л.Е., \& Нахимова, Е.А. (2017). Информационно-психологические войны в России. Политическая лингвистика, 3 (63), 140-145.

Воєнна доктрина Украӥни. Указ Президента України № 555/2015 від 24.09.2015. Режим доступу: http://www.president.gov.ua/documents/5552015-19443

Дударева, 3.М., Нахимова, Е.А., \& Рязанцева, Т.Ю. (2017). Лингвистика информационной войны против России, русского языка и православия: теория, методика и практика исследования. Актуальные проблемы филологии и педагогической лингвистики, 3, 47-53.

Зеленін, В.В. (2015). По той бік правди: нейролінгвістичне програмування як зброя інформаційно-пропагандистської війни. Київ: Люта справа.

Калуцков, В.Н. (2017). На Украине и в Украине: взгляд культурогеографа. Вестник Московского университета, 3, 79-88.

Компанцева, Л.Ф. (2018). Лінгвістична експертиза соціальних мереж. Київ: АграрМедіаГруп.

Кудінов, С., Компанцева, Л., Слухай, Н., Снитко, О., Акульшин, О., \& Заруба, О. (2018). Гібридна війна: технології сугестії та контрсугестії. Київ: Національна акадедмія СБ України.

Курбан, О.В., \& Курбан, С.О. (2019). Нейромаркетинг: реклама, PR, digitalmarketing, брендинг. Київ: Білий Тигр.

Лабуш, Н., \& Пую, А. (2019). Медиатизация экстремальныхх форм политического проиесса: война, революичя, терроризм. Санкт-Петербург: СанктПетербургский государственный университет.

Лисичкіна, I. (2019). Мас-медійні особливості побудови ефективного наративу як інструмента стратегічних комунікацій. Psycholinguistics. Психолінгвістика. Психолингвистика, 26 (2), 224-242. https://doi.org/10.31470/2309-1797-201926-2-224-242

Рогозин, Д. (2016). Война и мир в терминах и определениях: военно-технический словарь. Москва: Вече.

Русакова, О., \& Грибовод, Е. (2019). Информационно-коммуникативные компоненты «мягкой силы». Междунродные процессы, Т. 17, 1 (56), 62-72. https://doi.org/10.17994/IT.2019.17.1.56.4 
Русакова, О.Ф., \& Русаков, В.М. (2017). «Мягкая сила» как инструмент политической коммуникации и гуманитарной дипломатии. Дискурс-Пи, 1 (26), 61-72.

Сидоров, В.А., Быков, И.А., Гладченко, И.А., Декич, Э., Ж Жаворонкова, А.Н., Иванян, Р.Г. и др. (2019). Коммуникативные агрессии ХХІ века. СанктПетербург: Алетейя.

Сковородников, А.П., \& Копнина, Г.А. (2016). Лингвистика информационнопсихологической войны: к обоснованию и определению понятия. Политическая лингвистика, 1 (55), 42-49.

Сковородников, А.П. (Ред.). (2017). Лингвистика информачионно-психологической войны. Красноярск: Сибирский федеральный университет.

Шаховский, В.И. (2018). Может ли лингвистика повлиять на ход психологической войны? Вопросы психолингвистики, 35, 201-208. https://doi.org/10.30982/20775911-2018-35-1-200-208

Филлипс, Л.Дж., \& Йоргенсен, М.В. (2004). Дискурс-анализ. Теория и метод. Харьков: Гуманитарный центр.

AAP-06. NATO Glossary of Terms and Definitions (English and French). (2014). North Atlantic Treaty Organization NATO Standardization Office (NSO). Retrieved from wcnjk.wp.mil.pl/plik/file/N_20130808_AAP6EN.pdf

AJP-3.10.1 Allied Joint Doctrine for Psychölogical Operations Outlines NATO Psychological Operations. (2015). Retrieved from https://www.gov.uk/.../ajp3101-allied-joint-doctrine-forpsychological-operations

Commander's Handbook for Strategic Communication and Communication Strategy, Version 3.0. (2017). Suffolk, VA: Joint Warfighting Center. Retrieved from http:// www.dtic.mil/doctrine/doctrine/jwfc/sc hbk10.pdf

DOD. Dict. Dictionary of Military and Associated Terms. (2017). Retrieved from https://www.jcs.mil/Portals/36/Documents/ Doctrine/pubs/dictionary.pdf

Fake News: A Roadmap. (2019). Riga: King's Centre for Strategic Communications; the NATO Strategic Communications Centre of Excellence.

FM 3-13 IO: DTTP. Field Manual 3-13 Information Operations: Doctrine, Tactics, Techniques, and Procedures. (2016). Retrieved from https://www.globalsecurity. org/military/library/policy/army/fm/3-13/fm3-13_2016.pdf

Granelli, F. (2018). What does it Mean for a Communication to be Trusted? Defence Strategic Communications, 5, 171-214. https://doi.org/10.30966/2018.riga.5.5.

Haig, Z., \& Hajdu, V. (2017). New Ways in the Cognitive Dimension of Information Operations. Land Forces Academy Review, Vol. XXII, 2 (86), 94-102. https://doi. org/10.1515/raft-2017-0013

Holmstrom, M. (2015). The Narrative and Social Media. Defence Strategic Communication The official journal of the NATO Strategic Communications Centre of Excellence, 1 (1), 118-132. https://doi.org/10.30966/2018.riga.1.7

IMSM-0129-2018. Release of Psychological Operations and Information Operations Policies to Ukraine. (2018). International Military Staff; Etat-Major Militaire International. Retrieved from http://archives.nato.int/downloads/reports/militarycommittee-itemList.html

JDP 2-00. Joint Doctrine Publication 2-00 Understanding and Intelligence Support to Joint Operations. (2011). Retrieved from https://www.gov.uk/government/ publications/jdp-2-00-understanding-and-intelligence-support-to-joint-operations

JP 3-13.2. Joint Publication 3-13.2 Psychological Operations. (2010). Retrieved from https://fas.org/irp/doddir/dod/jp3-13-2.pdf 
Lange-Ionatamishvili, E. (2015). Strategic Communications and Social Media in the Russia Ukraine Conflict. Cyber War in Perspective: Russian Aggression against Ukraine (pp. 103-111). Tallinn: NATO CCD COE Publications.

Mayweg-Paus, E., \& Jucks, R. (2018). Conflicting Evidence or Conflicting Opinions? Two-Sided Expert Discussions Contribute to Experts' Trustworthiness. Journal of Language and Social Psychology, 37 (2), 203-223. https://doi. org/10.1177/0261927X17716102

Ovchinnikova, I. (2018). Effect of the Content Complexity on Hesitations in Adolescents' Narratives. Psychology of Language and Communication, 22 (1), 1-20. https://doi.org/10.2478/plc-2018-0001

Pamment, J. et al. (2018). The Role of Communicators in Countering the Malicious Use of Social Media. Riga: the NATO Strategic Communications Centre of Excellence.

Shaheen, J. (2015). Network of Terror: How DAESH Uses Adaptive Social Networks to Spread its Message. Riga: the NATO Strategic Communication Centre of Excellence

The Black Market for Social Media Manipulation. (2018). Riga: the NATO Strategic Communications Centre of Excellence.

\section{References}

Astashova, O.I., \& Bulatova, E.V. (2017). Problemy konstruirovaniya identichnosti rossiyan $v$ diskurse SMI pod vliyaniem konczepta «informaczionnaya vojna» [Problems of Constructing the Identity of Russians in the Discourse of the Media under the Influence of the "Information Warfare's» Concept]. Moscow; Ekaterinburg: Kabinetnyj uchenyj [in Russian].

Veprinczev, V.B., \& Manojlo, A.V. (2019). Operaczii informaczionno-psikhologicheskoj vojny: kratkij encziklopedicheskij slovar-spravochnik [Operations of the Information-Psychological Warfare: a Brief Encyclopedic Dictionary]. Moscow: Radio i svyaz [in Russian].

Vesnina, L.E., \& Nakhimova, E.A. (2017). Informaczionno-psikhologicheskie vojny $\mathrm{v}$ Rossii [Information-Psychological Warfares in Russia]. Politicheskaya lingvistika - Political Linguistics, 3 (63), 140-145 [in Russian].

Voyenna doktryna Ukrayiny [Military Doctrine of Ukraine]. Ukaz Prezydenta Ukrayiny № 555/2015 vid 24.09.2015 [Presidential Decree No 55/2015 of 24.09.2015]. Retrieved from http://www.president. gov.ua/documents/5552015-19443 [in Ukrainian].

Dudareva, Z.M., Nakhimova, E.A., \& Ryazanczeva, T.Yu. (2017). Lingvistika informaczionnoj vojny protiv Rossii, russkogo yazyka i pravoslaviya: teoriya, metodika i praktika issledovaniya [The Linguistics of Information Warfare against Russia, the Russian Language, and Orthodoxy: Theory, Methodology, and Practice of Research]. Aktualnye problemy filologii $i$ pedagogicheskoj lingvistiki - Current Issues in Philology and Pedagogical Linguistics, 3, 47-53 [in Russian].

Zelenin, V.V. (2015). Po toi bik pravdy: neirolinhvistychne prohramuvannia yak zbroia informatsiino-propahandystskoi viiny [Beyond the Truth: Neurolinguistic Programming as a Weapon of Outreach War]. Kyiv: Liuta sprava [in Ukrainian]. 
Kaluczkov, V.N. (2017). Na Ukraine i v Ukraine: vzglyad kulturgeografa [On Ukraine and in Ukraine: a View of the Cultural Geographer]. Vestnik Moskovskogo universiteta - Moscow State University Bulletin, 3, 79-88 [in Russian].

Kompantseva, L.F. (2018). Linhvistychna ekspertyza sotsialnykh merezh [Linguistic Examination of Social Networks]. Kyiv: AhrarMediaHrup [in Ukrainian].

Kudinov, S., Kompantseva, L., Slukhai, N., Snytko, O., Akulshyn, O., \& Zaruba, O. (2018). Hibrydna viina: tekhnolohii suhestii ta kontrsuhestii [Hybrid Warfare: Suggestion and Counter-Suggestion Technologies]. Kyiv: Natsionalna akadedmiia SB Ukrainy [in Ukrainian].

Kurban, O.V., \& Kurban, S.O. (2019). Neiromarketynh: reklama, PR, digital-marketing, brendynh [Neuromarketing: advertising, PR, digital-marketing, branding]. Kyiv: Bilyi Tyhr [in Ukrainian].

Labush, N., \& Puyu, A. (2019). Mediatizacziya ekstremalnykh form politicheskogo proczessa: vojna, revolyucziya, terrorizm [Mediation of Extreme Forms of the Political Process: War, Revolution, Terrorism]. St. Petersburg: SPbSU [in Russian].

Lysychkina, I. (2019). Mas-mediini osoblyvosti pobudovy efektyvnoho naratyvu yak instrumenta stratehichnykh komunikatsii [Mass-Media Specificity of Building an Effective Narrative as a Strategic Communication Tool]. Psykholinhvistyka Psycholinguistics, 26 (2), 224-242. https://doi.org/10.31470/2309-1797-2019-262-224-242 [in Ukrainian].

Rogozin, D. (2016). Vojna $i$ mir v terminakh i opredeleniyakh: voenno-tekhnicheskij slovar [War and Peace in Terms and Definitions: Military-Technical Dictionary]. Moscow: Veche [in Russian].

Rusakova, O., \& Gribovod, E. (2019). Informaczionno-kommunikativnye komponenty «myagkoj sily» [Information Components of Soft Power: Communicative Aspects]. Mezhdunrodnye proczessy - International Trends, Vol. 17, 1 (56), 6272. https://doi.org/10.17994/IT.2019.17.1.56.4 [in Russian].

Rusakova, O.F., \& Rusakov, V.M. (2017). «Myagkaya sila» kak instrument politicheskoj kommunikaczii i gumanitarnoj diplomatii [Soft Power as the Instrument of Political Communications and Humanitarian Diplomacy]. DiskursPi - Discurs-P, 1 (26), 61-72 [in Russian].

Sidorov, V.A., Bykov, I.A., Gladchenko, I.A., Dekich, E., Zhavoronkova, A.N., \& Ivanyan, R.G. (2019). Kommunikativnye agressii XXI veka [Communicative Aggressions of the 21st Century]. St. Petersburg: Aletejya [in Russian].

Skovorodnikov, A.P., \& Kopnina, G.A. (2016). Lingvistika informaczionnopsikhologicheskoj vojny: $\mathrm{k}$ obosnovaniyu $\mathrm{i}$ opredeleniyu ponyatiya [Linguistics of the Information-Psychological Warfare: to the Justification and Definition of the Concept]. Politicheskaya lingvistika - Political Linguistics, 1 (55), 42-49 [in Russian].

Skovorodnikov, A.P. (Ed.). (2017). Lingvistika informaczionno-psikhologicheskoj vojny [Linguistics of the Information-Psychological Warfare]. Krasnoyarsk: Sibirskij federalnyj universitet [in Russian].

Shakhovskij, V.I. (2018). Mozhet li lingvistika povliyat na khod psikhologicheskoj vojny? [Can Linguistics Influence the Course of Psychological Warfare?]. Voprosy psikholingvistiki - Journal of Psycholinguistics, 35, 201-208. https://doi. org/10.30982/2077-5911-2018-35-1-200-208 [in Russian].

Fillips, L.J., \& Jorgensen, M.V. (2004). Diskurs-analiz. Teoriya i metod [Discourse Analysis as Theory and Method]. Kharkov: Gumanitarnyj czentr [in Russian]. 
AAP-06. NATO Glossary of Terms and Definitions (English and French). (2014). North Atlantic Treaty Organization NATO Standardization Office (NSO). Retrieved from wcnjk.wp.mil.pl/plik/file/N_20130808_AAP6EN.pdf

AJP-3.10.1 Allied Joint Doctrine for Psychological Operations Outlines NATO Psychological Operations. (2015). Retrieved from https://www.gov.uk/.../ajp3101-allied-joint-doctrine-forpsychological-operations

Commander's Handbook for Strategic Communication and Communication Strategy, Version 3.0. (2017). Suffolk, VA: Joint Warfighting Center. Retrieved from http:// www.dtic.mil/doctrine/doctrine/jwfc/sc_hbk10.pdf

DOD. Dict. Dictionary of Military and Associated Terms. (2017). Retrieved from https://www.jcs.mil/Portals/36/Documents/Doctrine/pubs/dictionary.pdf

Fake News: A Roadmap. (2019). Riga: King's Centre for Strategic Communications; the NATO Strategic Communications Centre of Excellence.

FM 3-13 IO: DTTP. Field Manual 3-13 Information Operations: Doctrine, Tactics, Techniques, and Procedures. (2016). Retrieved from https://www.globalsecurity. org/military/library/policy/army/fm/3-13/fm3-13 2016.pdf

Granelli, F. (2018). What does it Mean for a Communication to be Trusted? Defence Strategic Communications, 5, 171-214. https://doi.org/10.30966/2018.riga.5.5.

Haig, Z., \& Hajdu, V. (2017). New Ways in the Cognitive Dimension of Information Operations. Land Forces Academy Review, Vol. XXII, 2 (86), 94-102. https://doi. org/10.1515/raft-2017-0013

Holmstrom, M. (2015). The Narrative and Social Media. Defence Strategic Communication The official journal of the NATO Strategic Communications Centre of Excellence, 1 (1), 118-132. https://doi.org/10.30966/2018.riga.1.7

IMSM-0129-2018. Release of Psychological Operations and Information Operations Policies to Ukraine. (2018). International Military Staff; Etat-Major Militaire International. Retrieved from http://archives.nato.int/downloads/reports/militarycommittee-itemList.html

JDP 2-00. Joint Doctrine Publication 2-00 Understanding and Intelligence Support to Joint Operations. (2011). Retrieved from https://www.gov.uk/government/ publications/jdp-2-00-understanding-and-intelligence-support-to-joint-operations

JP 3-13.2. Joint Publication 3-13.2 Psychological Operations. (2010). Retrieved from https://fas.org/irp/doddir/dod/jp3-13-2.pdf

Lange-Ionatamishvili, E. (2015). Strategic Communications and Social Media in the Russia Ukraine Conflict. Cyber War in Perspective: Russian Aggression against Ukraine (pp. 103-111). Tallinn: NATO CCD COE Publications.

Mayweg-Paus, E., \& Jucks, R. (2018). Conflicting Evidence or Conflicting Opinions? Two-Sided Expert Discussions Contribute to Experts' Trustworthiness. Journal of Language and Social Psychology, 37 (2), 203-223. https://doi. org/10.1177/0261927X17716102

Ovchinnikova, I. (2018). Effect of the Content Complexity on Hesitations in Adolescents' Narratives. Psychology of Language and Communication, 22 (1), 1-20. https://doi.org/10.2478/plc-2018-0001

Pamment, J. et al. (2018). The Role of Communicators in Countering the Malicious Use of Social Media. Riga: the NATO Strategic Communications Centre of Excellence.

Shaheen, J. (2015). Network of Terror: How DAESH Uses Adaptive Social Networks to Spread its Message. Riga: the NATO Strategic Communication Centre of Excellence 
The Phenomenon of Psychological Operations as a Concept...

The Black Market for Social Media Manipulation. (2018). Riga: the NATO Strategic Communications Centre of Excellence.

\begin{abstract}
АНОТАЦІЯ
Мета дослідження - обгрунтувати статус феномену психологічних операцій як концепту та дискурсу.

Методи та методики дослідження. Для отримання найдостовірніших результатів комплексно застосовано методи: семантико-когнітивного аналізу - для вивчення глибинних семантичних конотацій, що є принципово відмінними у лінгвокультурах НАТО і РФ; концепт-аналізу - для дослідження регулятивної ролі у міждержавних відношеннях концепту ПСИХОЛОГІчнІ ОПЕРАЦії; дискурс-аналізу - для вивчення послідовно ситуативного інституційного дискурсу психологічних операцій як інструменту конструювання соціальної реальності.
\end{abstract}

Результати дослідження. Дискурс доктрин НАTO має конструктивний вимір: він спрямований на формування позитивного іміджу Альянсу, привернення уваги до різноманітності цільових аудиторій, зміцнення довіри, підтримання дій командування щодо населення іноземних держав. Дискурс РФ орієнтований деструктивно: як актуальні виявлено стратегії уникнення міжнародної відповідальності, ігнорування дипломатичних відносин, нанесення шкоди, порівняної з наслідками бойових дій. Виявлено приховані смисли концепту ПСИХОЛОГІЧНІ ОПЕРАЦІї: в доктринах НАТО позиціонуються семантичні компоненти «просування стратегічних цілей задля відновлення та укріплення легітимності, полегшення страждань, підтримання та відновлення громадського порядку», в джерелах РФ - «напад під чужим прапором 3 метою дестабілізації та дезорієнтації». Лакунарність обумовлена моральноетнічним сприйняттям концепту ПСИХОЛОГІЧНІ ОПЕРАЦІї у досліджуваних лінгвокультурах.

Висновки. Дискурс психологічних операцій $\epsilon$ системою, напрями його розгортання у досліджуваних лінгвокультурах є принципово неконгруентними. Репрезентативність концепту ПСИХОЛОГІЧНІ ОПЕРАЦії у безпекових дискурсах демонструє інваріантні образи світу, співвіднесені з національною психологією.

Ключові слова: дискурсивна психологія, дискурсивне конструювання соціальної реальності, лакунарність концепту, концепт ПСИХОЛОГІЧНІ ОПЕРАЦІї, послідовно ситуативний інституційний дискурс психологічних операцій, психолінгвістичний вимір дискурсу психологічних операцій. 
Феномен психологічних операцій як кониепт $i$ дискурс...

Компанцева Лариса. Феномен психологических операций как концепт и дискурс (на материале лингвокультур сферы безопасности НАТО и Российской Федерации)

\section{АННОТАЦИЯ}

Цель исследования - обосновать статус феномена психологических операций как концепта и дискурса.

Методы и методики исследования. Для достижения наиболее достоверных результатов комплексно использованы методы: семантико-когнитивного анализа - для изучения глубинных семантических коннотаций, принципиально отличных в лингвокультурах НАТО и РФ; концепт-анализа - для исследования регулятивной роли в межгосударственных отношениях концепта ПСИХОЛОГИЧЕСКИЕ ОПЕРАЦИИ; дискурс-аналИза - для изучения последовательно ситуативного институционального дискурса психологических операций как инструмента конструирования социальной реальности.

Результаты исследования. Дискурс доктрин НАТО имеет конструктивное измерение: он нацелен на формирование позитивного имиджа Альянса, привлечение внимания к разнообразию целевых аудиторий, укрепление доверия, поддержку действий командования в отношении населения иностранных государств. Дискурс РФ ориентирован деструктивно: как актуальные отмечены стратегии избегания международной ответственности, игнорирования дипломатических отношений, нанесения ущерба, сопоставимого с результатами военных действий. Определен скрытые смыслы концепта ПСИХОЛОГИЧЕСКИЕ ОПЕРАЦИИ: в ЈоктрИнах НАТО позиционируются семантические компоненты «продвижение стратегических целей для восстановления и укрепления легитимности, облегчения страданий, поддержания и восстановления общественного порядка», в источниках РФ «нападение под чужим флагом с иелью дестабилизации и дезориентации». Лакунарность обусловлена морально-этническим восприятием концепта ПСИХОЛОГИЧЕСКИЕ ОПЕРАЦИИ в ИСследУемЫХ ЛИнгвоКУЛЬтУрах.

Выводы. Дискурс психологических операций является системой, направления его реализации в исследуемых лингвокультурах принципиально неконгруэнтны. Представленность концепта ПСИХОЛОГИЧЕСКИЕ ОПЕРАЦИИ в дискурсах сферы безопасности демонстрирует инвариантные образы мира, соотнесенные с национальной психологией.

Ключевые слова: дискурсивная психология, дискурсивное конструирование социальной реальности, лакунарность концепта, концепт ПСИХОЛОГИЧЕСКИЕ ОПЕРАЦИИ, последовательно ситуативный институциональный дискурс психологических операций, психолингвистическое измерение дискурса психологических операций. 